\title{
Carbon isotopic difference of saturated long-chain n-fatty acids between a terrestrial and a marine sediment
}

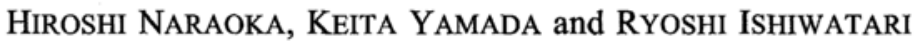 \\ Department of Chemistry, Faculty of Science, Tokyo Metropolitan University, \\ 1-1 Minami-Ohsawa, Hachioji, Tokyo 192-03, Japan
}

(Received June 22, 1994; Accepted December 15, 1994)

\begin{abstract}
Stable carbon isotopic compositions of individual $n$-fatty acids ranging from $\mathrm{C}_{20}$ to $\mathrm{C}_{30}$ in a terrestrial (riverine) and a marine (pelagic) sediment were determined using gas chromatography/isotope ratio monitoring mass spectrometry (GC/IRMS). These fatty acids in a terrestrial sediment at the Ohtsuchi river in northern Honshu Island, Japan, showed $\delta^{13} \mathrm{C}$ values (from -35 to $-32 \%$ relative to PDB) lighter than that of the total organic carbon (TOC; $-26.4 \%$ ) by about 6 to $9 \%$. The $\delta^{13} \mathrm{C}$ values from a marine sediment in the Pacific Ocean ca. $500 \mathrm{~km}$ off the coast of Honshu Island varied from -31 to $-26 \%$, which were also lighter than that of the TOC $(-20.5 \%)$ by 6 to $9 \%$. The $\delta^{13} \mathrm{C}$ values of $\mathrm{n}$-fatty acids ranging from $\mathrm{C}_{20}$ to $\mathrm{C}_{30}$ in the marine sediment were heavier by about 5 to $6 \%$ than those at the corresponding carbon numbers in the terrestrial one. Isotopically, the marine $\mathrm{n}$-fatty acids were clearly distinguished from the terrestrial ones. These results suggest that long-chain $\mathrm{n}$-fatty acids in marine sediment were not derived from land higher plant but from marine organisms, although long-chain $n$-fatty acids $\left(\geq C_{20}\right)$ in marine sediments have often been used to assess terrestrial material contribution to the ocean.
\end{abstract}

\section{INTRODUCTION}

Estimation of the proportions of terrestrial and marine organic materials in marine sediments is very important for the better understanding of the global carbon cycle. Discrimination of organic matter between two sources has often been conducted by ratio of total organic carbon (TOC) to nitrogen content $(\mathrm{C} / \mathrm{N})$ (Stevenson and Cheng, 1972; Muller, 1977) and isotopic composition of TOC (e.g. Degens, 1969; Sackett, 1987). The $\mathrm{C} / \mathrm{N}$ ratios in most marine sediments have lower values ( $<c a .8$ by weight) than those of terrestrial ones $(\mathrm{C} / \mathrm{N}>c a$. 10). Several studies clarified a systematic change in $\delta^{13} \mathrm{C}_{\mathrm{TOC}}$ values of sediments from rivers to bays and to open sea (Sackett and Tompson, 1963; Hunt, 1970; Wada et al., 1987). The $\delta^{13} \mathrm{C}_{\text {TOC }}$ values of open sea sediments are relatively constant ( $c a .-20 \%$ on average relative to PDB) and are heavier than those of terrestrial ones ( $c a .-26 \%$ on average). Accordingly, their values have been used to estimate the proportions of terrestrial and marine organic contributions in marine sediments. In molecular levels, organic compounds derived from lignin, suberin and cutin have been used as indicators of terrestrial materials (Hedges and Parker, 1976; Goni and Hedges, 1990), since they are characteristically contained in terrestrial higher plants (e.g. Kolattukudy, 1980).

Fatty acids, major components of lipids in sediments, have been difficult to determine their sources either marine or terrestrial, because they occur very widely in nature. Among saturated fatty acids, hexadecanoic $\left(\mathrm{n}-\mathrm{C}_{16}\right)$ and octadecanoic acid $\left(\mathrm{n}-\mathrm{C}_{18}\right)$ are abundant and may have originated from both marine and terrestrial biological materials. However, long-chain $n$-fatty acids $\left(\geq C_{20}\right)$ in marine sediments have been often used by many investigators (e.g. Simoneit, 1978; Brassel, 1993) to infer terrestrial higher plant input to the sediment through riverine or by aeolian transport, since they are usually predominant components in higher plant wax, suberin and cutin (e.g. Kolattukudy, 1980). Simoneit (1977) used the long-chain n-fatty 
acid as terrestrial indicators in the Black Sea sediments, where the major input mechanisms were potamic transport. Prahl et al. (1989) used the abundance of long-chain n-fatty acids to estimate the proportion of terrestrial to marine TOC in the sediments of northeastern tropical Pacific Ocean $\left(0^{\circ} 57.2^{\prime} \mathrm{N}, 138^{\circ} 57.3^{\prime} \mathrm{E}\right)$, where the fatty acids were assumed to be land-derived by long-range aeolian transport because of no major continental landmass nearby. However, the origin and mixing ratio of terrestrial and marine long-chain n-fatty acids in marine sediments have not been understood well. For instance, Volkman et al. (1980) pointed out the resemblance in molecular distribution of long-chain $\mathrm{n}$-fatty acids between intertidal sediment and marine organism (diatom).

Individual stable carbon isotopic compositions of abundant fatty acids (e.g. n- $\mathrm{C}_{16}$ and $\mathrm{n}-\mathrm{C}_{18}$ ) have been reported on various living organisms and sediments (Parker, 1962, 1964; Vogler and Hayes, 1980; Monson and Hayes, 1980, 1982) by isolating each compound using gas chromatography (GC) and subsequently oxidizing to $\mathrm{CO}_{2}$. Those of longchain n-fatty acids $\left(\geq C_{20}\right)$, however, have never been studied because of their relatively low abundances in sediments. In this study, we have determined the isotopic compositions of individual $\mathrm{n}$-fatty acids at even carbon numbers ranging from $\mathrm{C}_{20}$ to $\mathrm{C}_{30}$ in terrestrial (riverine) and marine (pelagic) sediments using a new technique of gas chromatography/isotope ratio monitoring mass spectrometry (GC/IRMS) (Matthews and Hayes, 1978; Hayes et al., 1990). We report their isotopic features and discuss the sources of long-chain $\mathrm{n}$-fatty acids in marine sediments.

\section{EXPERIMENTAL}

The terrestrial sample (OR3) used for this study was a riverine surface sediment which came from the Ohtsuchi river in Iwate-prefecture, northern Honshu Island, Japan. The marine sample (SR72) was a $36 \mathrm{~cm}$ core from the northwestern Pacific Ocean $\left(39^{\circ} 11.4^{\prime} \mathrm{N}, 147^{\circ} 06.2^{\prime} \mathrm{E}\right.$; about $500 \mathrm{~km}$ east off Honshu Island, or $250 \mathrm{~km}$ east from the Japan trench: $5360 \mathrm{~m}$ in depth) (Fig. 1). It was composed mainly of carbonate-free, diatom-rich siliceous matter. After subjected to the freezeddry procedure, the both sediment samples were treated with $6 \mathrm{M} \mathrm{HCl}$ to remove carbonate carbon. The TOC contents and $\mathrm{C} / \mathrm{N}$ ratios were determined using a CHN analyzer (Yanaco, MT-3), and $\delta^{13} \mathrm{C}_{\mathrm{TOC}}$ values by the method of $\mathrm{CuO}$-combustion in quartz tubes (Boutton et al., 1983) followed by the measurement of isotopic ratios using a double inlet mass spectrometer (Finnigan MAT delta S).

For fatty acid analysis, the SR72 sediment sample was a mixture taken from the part of 4 to

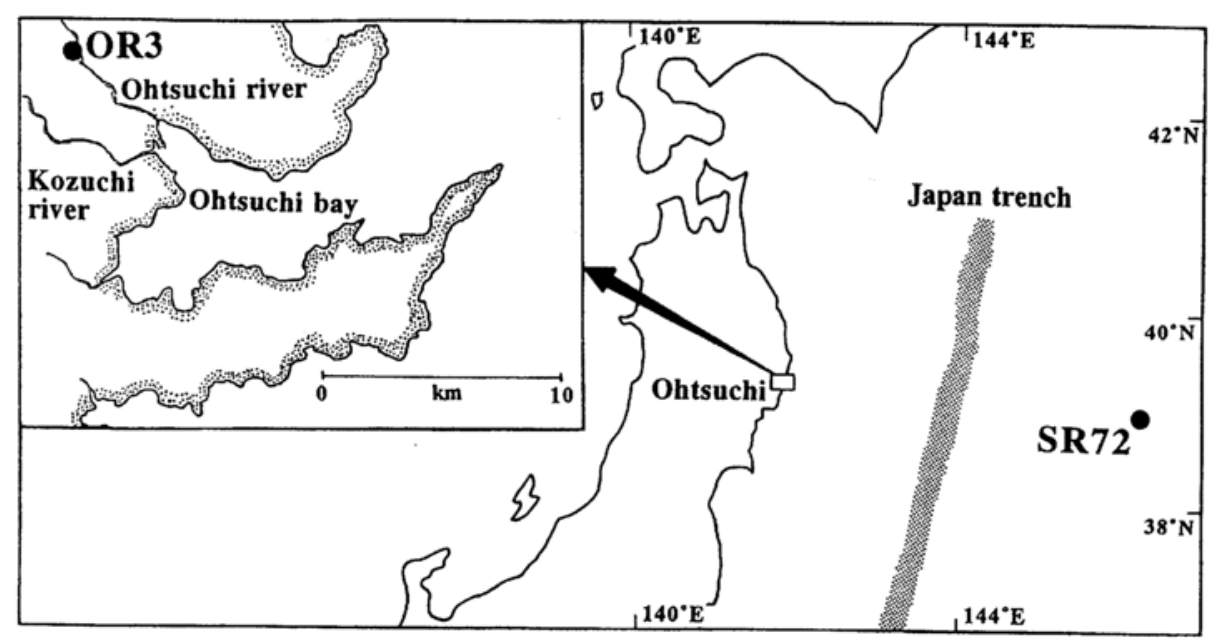

Fig. 1. Sampling sites of terrestrial (OR3) and marine (SR72) sediments (see text). 
$34 \mathrm{~cm}$ of the core. The samples were saponified with $0.5 \mathrm{M} \mathrm{KOH}$ in methanol by refluxing. After neutral organic compounds were removed, the fatty acid fraction was obtained and divided into two sub-fractions. One fraction was converted to trimethylsillyl derivatives, and analyzed by GC or gas chromatography/mass spectrometry (GC/MS). Another fraction was treated with $14 \% \mathrm{BF}_{3} / \mathrm{MeOH}$ to convert to the methyl ester derivatives, which were subsequently developed by a $\mathrm{AgNO}_{3}$-silica gel $(5 \% \mathrm{w} / \mathrm{w})$ column to isolate the saturated fatty acid fraction for the stable carbon isotope analysis by a GC/IRMS. The system used was a Finnigan MAT delta S mass spectrometer combined with a Varian 3400 gas chromatograph through a capillary combustion furnace $(\mathrm{CuO} / \mathrm{Pt})$.

Detailed analytical procedures and isotopic correction method will be reported elsewhere (Naraoka et al., 1994). Briefly, three n-alkanes as isotopic internal standards were coinjected with the samples. Isotopic correction was carried out for the fatty acids with one additional carbon atom using the $\delta^{13} \mathrm{C}$ values of methanol $(-37.4 \%)$ in $\mathrm{BF}_{3} /$ methanol. For standard $\mathrm{n}$-fatty acids, analytical accuracy (deviation of the corrected $\delta^{13} \mathrm{C}$ values determined by GC/IRMS from those determined by the conventional method) was $\pm 0.3 \%$ o for the average of several analyses. Precision (standard deviation $(s)$ defined as $s=\left(\Sigma\left(x_{i}-x_{\text {ave. }}\right)^{2 /}\right.$ $(n-1)^{1 / 2} ; x_{i}$ : measured values, $x_{\text {ave. }}$ : averaged value, $n$ : number of analyses) was within $0.3 \%$ $(s))$.

\section{RESULTS AND DISCUSSION}

TOC contents, $\mathrm{C} / \mathrm{N}$ ratios and carbon isotopic compositions of TOC of the sediments

The OR3 sediment had TOC content $3.19 \mathrm{wt} \%$, and $\mathrm{C} / \mathrm{N}$ ratio 10.8 with the $\delta^{13} \mathrm{C}_{\mathrm{TOC}}$ of $-26.4 \%$. For the SR72 sediment, these values were determined for every $2 \mathrm{~cm}$ through the core; the TOC content 0.66 (0.56 to 0.81$) \mathrm{wt} \%, \mathrm{C} / \mathrm{N}$ ratio 7.1 (6.6 to 7.9), and $\delta^{13} \mathrm{C}_{\mathrm{TOC}}$ of -20.5 ( -20.8 to $-20.1) \%$ on average used for this study. The ranges of measured values are shown in parentheses. The $\mathrm{C} / \mathrm{N}$ ratios and $\delta^{13} \mathrm{C}_{\mathrm{TOC}}$ values indi- cate that bulk organic matter in the OR3 and SR72 sediments have typical characteristics of terrestrial and marine sediment, respectively.

\section{Molecular distributions of fatty acids and other} terrigenous compounds

Relative abundances of major fatty acids in the sediments are shown in Fig. 2 (as the content of $\left.\mathrm{n}-\mathrm{C}_{16}=100\right)$. The contents of the most abundant fatty acid $\left(\mathrm{n}-\mathrm{C}_{16}\right)$ are quite different between OR3 (47 $\mu \mathrm{g} / \mathrm{g}$ dry sediment) and SR72 $(4 \mu \mathrm{g} / \mathrm{g}$ dry sediment). However, the relative abundances of saturated n-fatty acids ranging from $\mathrm{C}_{14}$ to $\mathrm{C}_{30}$ are not very different in both samples. The abundance pattern exhibits maxima in two regions (n$\mathrm{C}_{16}$, and $\mathrm{n}-\mathrm{C}_{22}$ (OR3) or $\mathrm{n}-\mathrm{C}_{26}$ (SR72)). This bimodal distribution has been commonly observed in marine sediments (e.g. Simoneit, 1978; Nishimura and Baker, 1987) and sedimentary rocks (e.g. Grimalt et al., 1990). Furthermore, both have the predominance of even carbon numbered fatty acids. For long-chain n-fatty acids, the abundance ratio of even to odd carbon-numbered molecules (defined here as $\left(\mathrm{n}-\mathrm{C}_{22}+\mathrm{n}-\mathrm{C}_{24}+\mathrm{n}-\mathrm{C}_{26}+\mathrm{n}-\mathrm{C}_{28}\right)$ / $\left(\mathrm{n}-\mathrm{C}_{21}+\mathrm{n}-\mathrm{C}_{23}+\mathrm{n}-\mathrm{C}_{25}+\mathrm{n}-\mathrm{C}_{27}\right)$, where $\mathrm{n}-\mathrm{C}_{\mathrm{m}}$ represents the contents of $n-C_{m}$ fatty acid) are 3.4 and 4.1 for the OR3 and SR72 sediments, respectively. Therefore, it is impossible to determine whether the long-chain n-fatty acids in the SR72 sediment are terrestrial and/or marine in origin only by their relative abundances.

In addition to the dominance of saturated nfatty acids, $\omega$-hydroxymonocarboxylic and $\alpha, \omega$ dicarboxylic acids ranging from $\mathrm{C}_{14}$ to $\mathrm{C}_{26}$ at even carbon numbers are prominent components in the OR3, but less in the SR72 sediment (Fig. 2). These acid mixtures are characteristic of cutin and suberin compounds from land higher plants (Kolattukudy, 1980). Unsaturated $\left(\mathrm{C}_{18: 1}\right) \omega$ hydroxymonocarboxylic and $\alpha, \omega$-dicarboxylic acid may be used to distinguish terrestrial organic contribution from marine one in the sediments. Furthermore, alkaline $\mathrm{CuO}$ oxidation of the sediments revealed that lignin-derived compounds such as vanillyl and syringyl phenols with aldehyde, ketone and carboxyl functional groups were more 


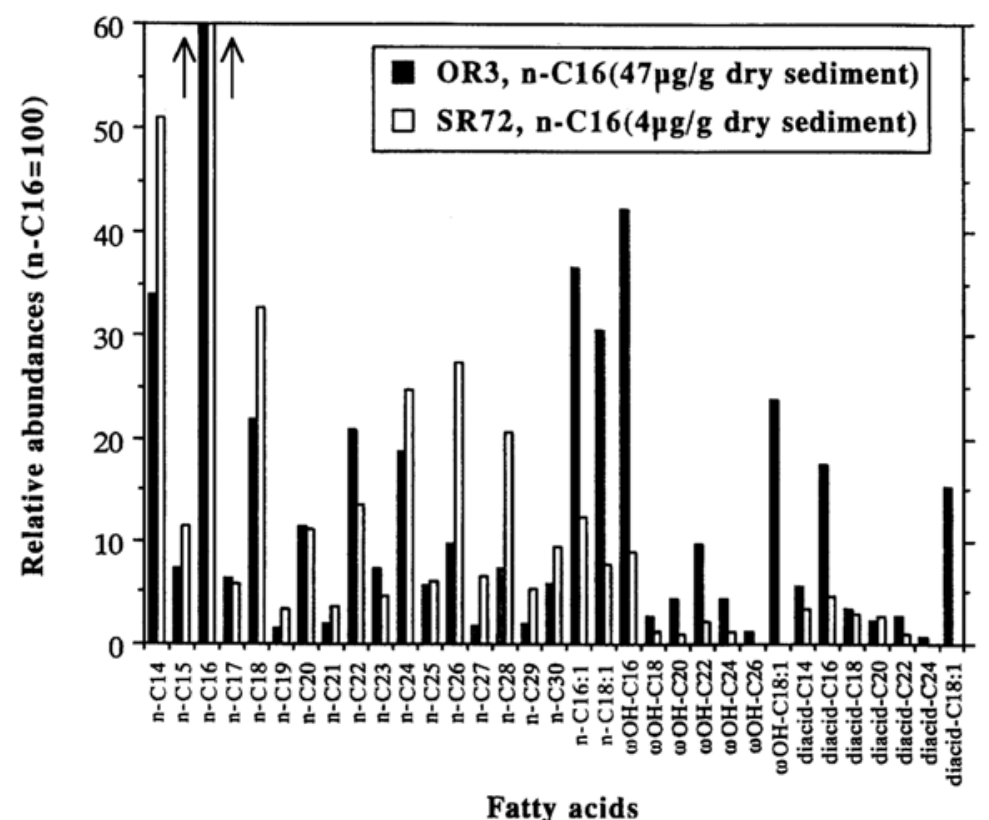

Fig. 2. Relative abundances of fatty acids in the OR3 and SR72 sediments. Each fatty acid is normalized to the most abundant fatty acid, hexadecanoic acid $\left(n-C_{16}\right)(=100)$. The term, $m$, represents the carbon number of fatty acid. $n-C_{m}=$ saturated $n$-fatty acid, $n$ - $C_{m: 1}=$ monounsaturated $n$-fatty acid, $\omega-O H-C_{m}=\omega$-monohydroxy saturated fatty acid, $\omega$-OH- $C_{m: 1}=\omega$-monohydroxy monounsaturated fatty acid, $C_{m}=\alpha, \omega$-dicarboxylic saturated $n$ fatty acid, diacid $C_{m: 1}=\alpha, \omega$-dicarboxylic monounsaturated n-fatty acid.

abundant in the OR3 $(\mathrm{ca} .1000 \mu \mathrm{g} / \mathrm{g}$ dry sediment) than in the SR72 (ca. $10 \mu \mathrm{g} / \mathrm{g}$ dry sediment) (Ishiwatari, unpublished result). Terrestrial contribution of organic matter must be low in the SR72 sediment.

Carbon isotopic compositions of individual longchain n-fatty acids in the OR3 and SR72 sediment, and possible sources of the long-chain $n$-fatty acids in the SR72 sediment

Figure 3 shows the $\delta^{13} \mathrm{C}$ values of individual $\mathrm{n}$-fatty acids at even carbon numbers in the two sediments. The $\mathrm{C}_{20}-\mathrm{C}_{30}$ fatty acids in the OR3 sediment have lighter $\delta^{13} \mathrm{C}$ values (from -35 to $-32 \%$ ) than that of TOC $(-26.4 \%$ ) by 6 to $9 \%$. The result is consistent with the previous studies that $\mathrm{n}-\mathrm{C}_{16}$ and $\mathrm{n}-\mathrm{C}_{18}$ fatty acids including saturated and unsaturated structures have usually lower $\delta^{13} \mathrm{C}$ values than those of total organisms (Parker, $1962,1964)$. On the other hand, these $\delta^{13} \mathrm{C}$ values in the SR72 sediment vary from -31 to $-26 \%$, which are also lighter than that of TOC $(-20.5 \%)$ by 6 to $10 \%$. The $\delta^{13} \mathrm{C}$ values of $\mathrm{n}$-fatty acids ranging from $\mathrm{C}_{20}$ to $\mathrm{C}_{30}$ in the SR72 sediment are heavier by 5 to $6 \%$ than those of the corresponding carbon numbers in the OR3 sediment. The result indicates that the marine n-fatty acids can be distinguished clearly from those in terrestrial ones isotopically.

Saturated fatty acids in organisms are synthesized through elongation of acetyl-CoA (e.g. Hitchcock and Nichols, 1971). Or it is suggested that exogenous fatty acids are incorporated into phospholipids (Silbert et al., 1968; Monson and Hayes, 1980). In any case, the $\delta^{13} \mathrm{C}$ value of $\mathrm{n}$ fatty acid in sediment depends on the isotopic composition of carbon source where the fatty acid is biosynthesized. Therefore, the $\delta^{13} \mathrm{C}$ value differences of individual $\mathrm{n}$-fatty acids between the OR3 and SR72 sediments are due to (i) the difference in primary producers, i.e. terrestrial or marine carbon fixers under different conditions, 


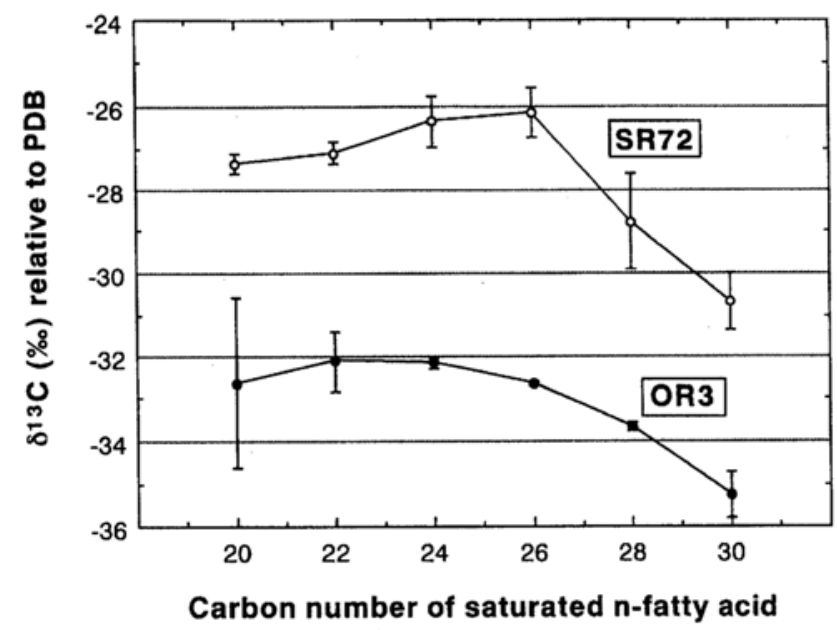

Fig. 3. Carbon isotopic compositions of individual saturated n-fatty acid (corrected from those of methyl ester derivatives) ranging from $C_{20}$ to $C_{30}$ at even carbon numbers in the OR3 and SR72 sediments. The $\delta^{13} C$ values were obtained by duplicate and triplicate analyses for OR3 and SR72 sediments, respectively. Error bars represent standard deviations $2 s$ ( $\pm s$ ).

(ii) the isotopic shift by biological reworking and early diagenesis during transportation and deposition, and/or (iii) the difference of age dependent environmental conditions such as temperature and partial pressure of atmospheric $\mathrm{CO}_{2}$ during photosynthetic fixation. The alternative (iii) could arise from the reason that the SR72 is not young sediment, which deposited from $c a$. 20 to 150 thousand years ago, because sedimentation rate for the SR72 sediment is quite small $(2.3 \mathrm{~mm} / \mathrm{kyr})$ (Narita et al., 1990). However, the $\delta^{13} \mathrm{C}$ values of bulk organic carbon are practically constant $(-20.5 \pm$ $0.3 \%$ ) throughout the sediment core. It suggests that drastic environmental change, which had caused the isotopic shift of fatty acids by $c a .5 \%$, has not occurred in this region during the past 150 thousand years. Therefore, the last alternative is much less plausible.

For the alternative (ii), the isotopic shift of fatty acids by biological reworking and diagenesis is not well known. Diagenesis involving decarboxylation of carboxyl groups may make the carbon isotopes of total fatty acids heavier, because biologically-formed carboxyl groups are usually depleted in ${ }^{13} \mathrm{C}$ relative to their corresponding molecular average within 10\% (Vogler and Hayes, 1980; Monson and Hayes, 1982). So decarboxy- lation of fatty acids could contribute to increase the $\delta^{13} \mathrm{C}$ value by $1 \%$ or less as a whole molecule, even if the reaction is followed by oxidation to produce other shorter chain fatty acids. Furthermore, it is important to realize that longchain $n$-fatty acids $\left(>\mathrm{C}_{20}\right)$ are not utilized well by organisms because they are not better primary substrate as energy sources in various living organisms than abundant fatty acids of $\mathrm{C}_{14}, \mathrm{C}_{16}$ and $C_{18}$ (Nishimura and Baker, 1987). These considerations may indicate that the $\delta^{13} \mathrm{C}$ values of longchain n-fatty acids in the two sediments have not little changed in these processes of alternative (ii).

The alternative (i) is most plausible by the following reason. The $n$-fatty acids in the OR3 and SR72 sediments show equally lighter $\delta^{13} \mathrm{C}$ values than that of TOC by about 6 to $9 \%$. The isotopic difference could reflect the isotope difference of primary substrates depending on the terrestrial or marine assimilation process. It is known that $\delta^{13} \mathrm{C}$ values of total lipid extracts for various plant and plankton species are lighter than those of TOC by $5 \%$ on average (Degens, 1969; Deines, 1980). Therefore, we may conclude that long-chain n-fatty acids $\left(\mathrm{C}_{20}-\mathrm{C}_{30}\right)$ in the SR72 sediment are not derived from land higher plants but from organisms in marine environment. Our 
finding indicates the necessity of reconsideration of reliability of these compounds as an indicator of terrestrial organic matter.

As mentioned above, Volkman et al. (1980) reported the resemblance of molecular distribution of long-chain fatty acids between intertidal sediment and diatom culture. Recently, some seagrass species were found to contain the long-chain nfatty acids (Khotimchenko, 1993). Microscopic observation revealed that the SR72 sediment was composed mainly of diatomaceous phytoplankton. Diatom is probably the best candidate for the source of the long-chain n-fatty acids in the SR72 sediment. In pelagic sediments, siliceous matter is one of the important components as well as calcareous matter and red clays. Siliceous sediments as opal are known to be widely distributed around the perimeter of the Antarctic continent, along the equatorial belt in the Pacific, off the coast of Africa in the Atlantic, and in the northernmost Pacific (Broecker and Peng, 1982). Diatom is suggested to contribute to the high primary productivity in these regions (Broecker and Peng, 1982). Long-chain $n$-fatty acids may be widely distributed in pelagic sediments because of widespread occurrence of siliceous sediments and activity of diatoms. In fact, long-chain fatty acids were detected in the tropical Pacific Ocean (Prahl et al., 1989), and in siliceous, calcareous and red clay sediments from $-15^{\circ} \mathrm{S}$ to $50^{\circ} \mathrm{N}$ along $175^{\circ} \mathrm{E}$ in the Pacific (Ohkouchi, personal communication).

\section{Conclusions}

This study suggests that $\mathrm{n}$-fatty acids ranging from $\mathrm{C}_{20}$ to $\mathrm{C}_{30}$ in marine sediments cannot be used as a reliable indicator of terrestrial organic matter input to the ocean, and that the use of biomarker approach should be accompanied with stable carbon isotopic compositions. Stable carbon isotopic compositions of individual fatty acids in sediments could give quite useful information on their terrestrial or marine sources.

Acknowledgments-The authors thank Dr. S. Montani for providing us with a pelagic sediment and useful information about the sample. We also acknowledge Dr. M. Iwai for giving us information on diatom distribution in the SR72 sediment. We appreciate helpful discussion with Dr. N. Ohkouchi and the technical comments of Mrs. H. Uemura and T. Yada. This work was supported by a Grant-in-Aid for Scientific Research from the Japanese Ministry of Education, Science and Culture.

\section{REFERENCES}

Boutton, T. W., Wong, W. W., Hachey, D. L., Lee, L. S., Cabrera, M. P. and Klein, P. D. (1983) Comparison of quartz and Pyrex tubes for combustion of organic samples for stable carbon isotope analysis. Anal. Chem. 55, 1832-1833.

Brassel, S. C. (1993) Applications of biomarkers for delineating marine paleoclimatic fluctuations during the Pleistocene. Organic Geochemistry; Principles and Applications (Engel, M. H. and Macko, S. A., eds.), 699-738, Plenum Press, New York.

Broecker, W. S. and Peng, T.-H. (1982) Tracers in the Sea. Lamont-Doherty Geological Observatory, New York, 690 pp.

Degens, E. T. (1969) Biogeochemistry of stable carbon isotopes. Organic Geochemistry; Methods and Results (Eglinton, G. and Murphy, M. T. J., eds.), 304-329, Springer-Verlag Berlin, Heidelberg.

Deines, P. (1980) The isotopic composition of reduced carbon. Handbook of Environmental Isotope Geochemistry, Vol. 1; The Terrestrial Environment, A (Fritz, P. and Fontes, J. Ch., eds.), 329-406, Elsevier, Amsterdam.

Goni, M. A. and Hedges, J. I. (1990) The diagenetic behavior of cutin acids in buried conifer needles and sediments from a coastal marine environment. Geochim. Cosmochim. Acta 54, 3073-3081.

Grimalt, J. O., Angulo, L., Lopez-Galindo, A., Comas, M. C. and Albaiges, J. (1990) Lipid and mineralogical composition of the Cretaceous black shale deposits of the Fardes Formation (southern Iberian Paleomargin, Betic Cordillera, south Spain). Chem. Geol. 82, 341-363.

Hayes, J. M., Freeman, K. H., Popp, B. N. and Hoham, C. H. (1990) Compound-specific isotopic analyses: A novel tool for reconstruction of ancient biogeochemical processes. Org. Geochem. 16, 1115-1128.

Hedges, J. I. and Parker, P. L. (1976) Land-derived organic matter in surface sediments from the Gulf of Mexico. Geochim. Cosmochim. Acta 40, 10191029.

Hitchcock, C. and Nichols, B. W. (1971) Plant Lipid Biochemistry. Academic Press, London.

Hunt, J. M. (1970) The significance of carbon isotope 
variations in marine sediment. Advances in Organic Geochemistry, 1966 (Hobson, G. O. and Speers, G. C., eds.), 27-35, Pergamon, London.

Khotimchenko, S. V. (1993) Fatty acids and polar lipids of seagrasses from the sea of Japan. Phytochemistry 33, 369-372.

Kolattukudy, P. E. (1980) Cutin, Suberin, and Waxws. The Biochemistry of Plants, Vol. 4, 571-645, Academic Press, London.

Matthews, D. E. and Hayes, J. M. (1978) Isotope-ratio-monitering gas chromatography mass spectrometry. Anal. Chem. 50, 1465-1473.

Monson, K. D. and Hayes, J. M. (1980) Biosynthetic control of the natural abundance of carbon 13 at specific positions within fatty acids in Escherichia coli. J. Biol. Chem. 255, 11435-11441.

Monson, K. D. and Hayes, J. M. (1982) Carbon isotopic fractionation in the biosynthesis of bacterial fatty acids. Ozonolysis of unsaturated fatty acids as a means of determining the intramolecular distribution of carbon isotopes. Geochim. Cosmochim. Acta 46, 139-149.

Muller, P. J. (1977) C/N ratios in Pacific deep-sea sediments: Effect of inorganic ammonium and organic nitrogen compounds sorbed by clays. Geochim. Cosmochim. Acta 41, 765-776.

Naraoka, H., Yamada, K. and Ishiwatari, R. (1994) Stable carbon isotope measurement of individual fatty acids using gas chromatography/isotope ratio monitoring mass spectrometry. J. Mass Spectrom. Soc. Jpn. 42, 315-323.

Narita, H., Harada, K. and Tsunogai, S. (1990) Natural radionuclides in marine sediments. Abst. Ann. Meeting Geochem. Soc. Jpn., Niigata, 156-157 (in Japanese).

Nishimura, M. and Baker, E. W. (1987) Compositional similarities of non-solvent extractable fatty acids from recent marine sediments deposited in differing environments, Geochim. Cosmochim. Acta 51, 13651378.

Parker, P. L. (1962) The isotopic composition of the carbon of fatty acids. Carnegie Inst. Washington Yearbook 61, 187-190.
Parker, P. L. (1964) The biogeochemistry of the stable isotopes of carbon in marine bay. Geochim. Cosmochim. Acta 28, 1155-1164.

Prahl, F. G., Muehlhausen, L. A. and Lyle, M. (1989) An organic geochemical assessment of oceanographic conditions at MANOP site $\mathrm{C}$ over the past 26,000 years. Paleoceanogr. 4, 495-510.

Sackett, W. M. and Tompson, R. R. (1963) Isotopical organic carbon composition of recent continental derived clastic sediments of the eastern Gulf of Mexico. Am. Assoc. Pet. Geol. Bull. 47, 525-528.

Sackett, W. M. (1987) Stable carbon isotope studies on organic matter in the marine environment. Handbook of Environmental Isotope Geochemistry, Vol. 3; The Marine Environment, A (Fritz, P. and Fontes, J. Ch., eds.), 139-169, Elsevier, Amsterdam.

Silbert, D. F., Ruch, F. and Vagelos, P. R. (1968) Fatty acid replacements in a fatty acid auxotroph of Escherichia coli. J. Bacteriol. 95, 1658-1665.

Simoneit, B. R. T. (1977) The Black Sea, a sink for terrigeous lipids. Deep-Sea Res. 24, 813-830.

Simoneit, B. R. T. (1978) The organic chemistry of marine sediments. Chemical Oceanography Vol. 7 (Riley, J. P. and Chester, R., eds.), 233-311, Academic Press, London.

Stevenson, F. J. and Cheng, C.-N. (1972) Organic geochemistry of the Argentine Basin sediments: carbon-nitrogen relationships and Quaternary correlations. Geochim. Cosmochim. Acta 36, 653-671.

Vogler, E. A. and Hayes, J. M. (1980) Carbon isotopic compositions of carboxylgroups of biosynthesized fatty acids. Advances in Organic Geochemistry 1979 (Douglas, A. G. and Maxwell, J. R., eds.), 697-704, Pergamon, London.

Volkman, J. K., Johns, R. B., Gillan, F. T., Perry, G. J. and Bavor, H. J., Jr. (1980) Microbial lipids of an intertidal sediment-I. Fatty acids and hydrocarbons. Geochim. Cosmochim. Acta 44, 1133-1143.

Wada, E., Minagawa, M., Mizutani, H., Tsuji, T., Imaizumi, R. and Karasawa, K. (1987) Biogeochemical studies on the transport of organic matter along the Otsuchi River watershed, Japan. Estuarine Coastal and Shelf Science 25, 321-336. 